\title{
The Underrepresentation of Iranian Females in Business Leadership Positions: A Qualitative Case Study
}

\author{
Dariush Vazvan \\ University of Phoenix \\ Arizona, United States of America
}

\begin{abstract}
Although $60 \%$ of university students in Iran are females as a result of huge investments in women's education, highly educated females occupy only $10 \%$ of leadership positions (Arasti, 2012). The purpose of this study was to clarify from Iranian female business leaders' perspective the reason or reasons behind such a gap. In this research female business leaders explain their perception about barriers that hinder Iranian females from obtaining higher positions in business organizations. This research was conducted in Tehran, the capital city of Iran, and data was gathered by interviewing female business leaders who have experienced obstacles and barriers to obtaining higher positions. Based on the research questions, familial, cultural, and political barriers were studied and findings were analysed and evaluated. Because there are similarities between Iran and other Middle Eastern countries (Owen, 2000), the findings of this study may be significant to understand obstacles that females in Middle Eastern countries face in their progress to their empowerment and occupying decision-making positions.
\end{abstract}

Keywords: Women, Leadership, Iran, Discrimination, Glass ceiling, Business, Organization, Female

\section{*Corresponding author: Dariush Vazvan; Email: dariush.vazvan@normedco.com} DOI: https://doi.org/10.37227/jibm-2021-02-98

\section{Introduction}

While higher levels of education are believed to improve a person's chances for promotion in the business world, there is a contradiction between the number of educated Iranian females and their representation in the business world as leaders (Arasti, 2012). Since all Iranian university students are required to pass rigorous entrance examinations, and since more than $60 \%$ of the students enrolled in Iranian universities are women, academic ability is not an issue (Shavarini, 2003). Given that many Iranian women are not able to enter careers that align with the degrees they have earned (Bianchi, 2005), there appear to be other factors contributing to this situation.

According to Ahl (2002), female business leaders are noteworthy, not only for their talents but also for their persistence. This is in spite of different movement that women have had since post war II for equal rights (Nickerson, 2012). In the Middle East, their accomplishments are considered to be even more extraordinary, despite substantial restrictions (Richardson, 2013). For example, women in Iran are required to follow the directives of the conservative clerics who are in positions of power (Mohammadi, 2007). The focus of this research study was to determine potential reasons that females are so underrepresented in business leadership positions in Iran. 


\section{Literature Review}

Background shows that from 1900 to present there have been several women's movements in Iran. The Anjoman-e Azadi-ye Zanaan (the Women's Freedom Society), began as a secret underground group (Mahdi, 2004). Many male Iranian students who returned to their homeland from Europe wanted to change their society (Mohammadi, 2007), and lead protests that resulted in the establishment of constitutional law and a parliament in 1906 (Brown, 1966).

However, the establishment of parliament did not bring about immediate societal reforms (Balaghi, 2014). In 1911, a member of parliament introduced a bill to grant voting rights to women, but the bill was rejected by the clerics (Mahdi, 2004) who did not support females' participation in politics or see the need for them to be educated (Cooke, 2000). During Iran's Constitutional Era (1905 - 1911), a large number of Iranian intellectuals advocated for an end to the practice of veiling (Shirazi, 2012).

After the Islamic revolution in 1979, veiling was again required (Shahidian, 2002). At this point in Iran's history, the country's intellectuals determined that women's rights extended beyond how they were dressed in public (Sarafraz \& Faghih, 2011), and they advocated for higher education as a means to enhance the status of Iranian women (Kamyab, 2004). Despite the fact that over $60 \%$ of the students in Iranian universities are female (Kamyab), only $9.16 \%$ of the leadership positions in Iranian businesses are held by women, which is significantly less than the $13.89 \%$ regional average (Sarafraz \& Faghih, 2011).

The general problem is that Iranian females are underrepresented in their country's business leadership positions. Education alone does not necessarily empower women's position in the Iranian society. For example, Moinifar (2012) has stated that higher education of women in Iran is not necessarily an achievement because unemployment among women with higher education has increased. Although the government promotes females' education, authorities do not seem to appreciate higher education of women. Morley (2014) has stated that authorities in Iran have put bans in universities to require acceptance of females. Perhaps the purpose of such bans is to reduce the number of candidates for leadership positions among women. Javadian and Singh (2012) stated that negative stereotypes and traditions are barriers that Iranian women have to overcome.

The specific problem is that despite the fact that after the Revolution of 1979 Iranian intellectuals promoted higher education for females as a way for them to advance (Morley, 2014; Moinifar, 2012; Javadian \& Singh, 2012; Kamyab, 2004), opportunities for Iranian females to secure leadership positions in traditional business enterprises or as entrepreneurs do not appear to have increased. To summarize, while $40 \%$ of the students attending Iranian universities are male, they hold more than $90 \%$ of the business leadership positions in that country (Figure 1, based on research of Arasti 2012). 


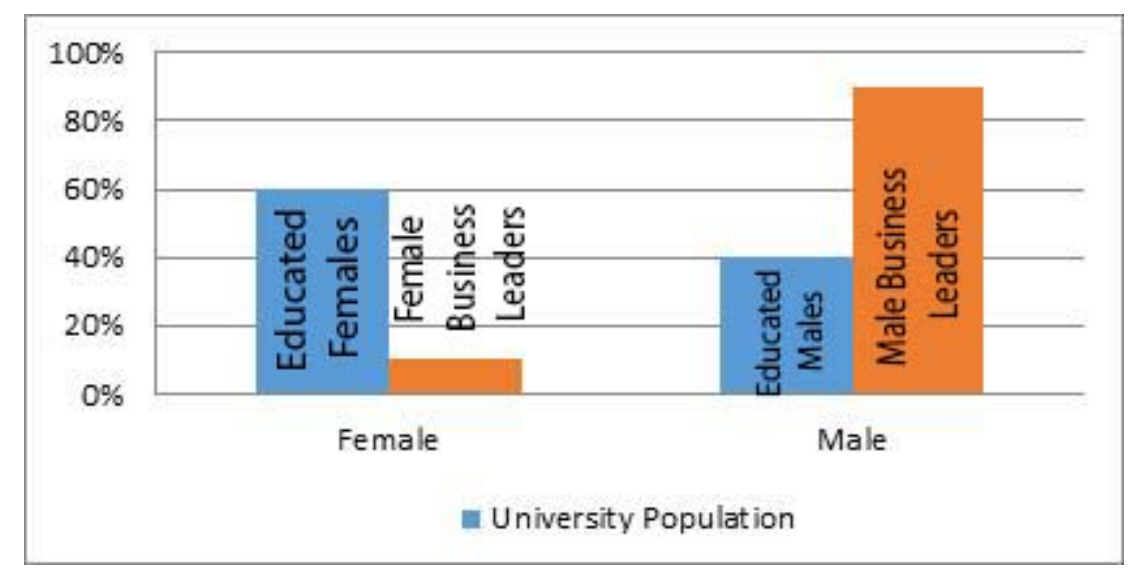

Figure 1. Gender of Iranian University population vs. business leadership positions, created by researcher based on Arasti (2012) and Kamyab (2004) findings.

According to William (2012) based on conservative nature of Iranian societal norms, women are not seen as being as capable as men in making business decisions, and therefore they cannot be as successful as men in these types of leadership positions. Even in the $21^{\text {st }}$ century, the country's culture is still dominated by male values and even college educated females have difficulty entering careers that align with their completed degree programs. William (2012) notes that:

Over the past three decades, Iranian women emerged to a more prominent position in the labor force, but these gains have been undercut by traditional trends that oppress women inside the system that aids their advancement (para. 1).

Despite the challenges they have encountered in their country, Iranian women have achieved recognition for their achievements (Kashani-Sabet, 2011). According to Isfandyari et al. (2012), Iranian women who perform and publish research are mostly motivated by the following reasons: getting promoted in scientific rank, getting promoted in a job, and feeling useful in society. However, the increasing educational levels of Iranian females have sparked social unrest (The World Bank, 2014). For example, the compulsory veiling that the Iranian government introduced as an Islamic value has been an ongoing subject of conflict for its citizens (Abdo, 2006).

In conducting this study, the researcher hoped to discover why there is such a large difference between the number of male and female business leaders in Iran. The effects of the complex cultural and social barriers that exist in Iran and how they affect leadership, social, and economic development of females will be explored. The issues and concerns that Iranian females experience are similar to those faced in other Middle Eastern and North African countries (Owen, 2000).

Beside this, Iran is a developing country that needs the participation of both males and females to build the country (Ebrahimian, 2003). Therefore, it is important to have first-hand and accurate information about the challenges women face, since they generally comprise about $50 \%$ of the population.

Gender standards and democratic standards are usually correlated, and pressures that drive the adoption of gender policies may also promote the adoption of democratic systems (Mili, 2013). According to Ghanim (2009), a critique of social and cultural values in the Middle East can yield more tolerance and a better balance between genders. Gender violence in the Middle East in general hinders women from participating more in social and political activities that can create better opportunities for women. 
The results of this study may contribute new knowledge about the importance of female business leaders in male-dominated societies like Iran and the contributions that women can make to the country's development. The wider influence of women can lead to more stability, and even to peace (Vavrus, 2003). According to Nuket (2002), gender issues are a global concern and scholars should identify the issue and show how it is affecting societies and the world.

\section{Research Methodology}

Since the purpose of this study was to provide information about a particular case, an explanatory single case study methodology was selected as the most appropriate. An explanatory single case study allows the researcher to understand the interactions of women with government institutions, financial organizations, or other entities, and allows the researcher to interpret the challenges faced by Iranian female business leaders. The target population of this case study was Iranian businesswomen who have been in business 10 or more years. Participants in this case study had tried to gain leadership position or had left their organizations and established their own businesses. The sample is minimum of six and a maximum of 10 participants who meet the criteria already stated. Association of Iranian Female Entrepreneurs helped the researcher to find participants who were members of the association as well.

Female participants who are aware of challenges that women face in Iran in obtaining business leadership positions were interviewed. The researcher conducted faceto-face interviews with Iranian women who have experienced the challenges of becoming business leaders or starting their own enterprises.

The research questions explored in this study were:

RQ1: What are the perceived cultural barriers that limit Iranian females' representation in business leadership positions?

RQ2: What are the perceived social barriers that limit Iranian females' representation in business leadership positions?

RQ3: What are the perceived political barriers that limit Iranian females' representation in business leadership positions?

\section{Conceptual Framework}

The theoretical framework of this study included patriarchy, social capital, and the glass ceiling. Each of these frameworks directly impact females throughout the world as they navigate the intricacies of becoming business leaders. Sorokina (2014) has stated that the number of female business leaders in the world's countries, except for Norway, does not exceed 20 percent.

Patriarchy: Much of the literature indicates that Iran is a patriarchal society (Mahdavi, 2003), or one that subordinates and exploits women publicly and privately. In most developing countries women are sexually dominated and are not granted certain privileges because of their gender (Semali \& Shakespeare, 2014). The private form of patriarchy is evidenced by women being controlled by the male head of the family. In public patriarchy, women become victims of segregation and discrimination in the form of lower salaries and limited access to public institutions (Mahdavi, 2003). According to Halimi, Bagherzad, Chavosh, Namdar, and Behjati (2011), Iranian men purposefully create barriers to limit women's freedom because it is assumed that it is hard to control independent women. 
Social capital: In traditional countries like Iran, it is difficult for women to access financial resources and become a part of business social networks (Arasti, 2012). When a woman establishes her own business enterprise, having enough money or being able to borrow it may be an issue (Hakala, 2007). As a result, potential investors may be reluctant to provide the necessary backing because of difficulty in founding or growing a femaleowned business in this type of environment (Hakala, 2007). Sarafraz (2017) in her book has referred to a study done by Rabiee and Sarabi (2013) that shows three dimensions of social capital in Iran including the structural, relational, and cognitive aspects. This study suggests structural social capital that includes network ties is not strong among women. Sarafraz (2017) also mentions that, according to research based on Global Entrepreneurship Monitor (GEM), the greater number of male entrepreneurs in Iran somehow is related to social capital.

According to Woolcock and Narayan (2000), social capital leads to economic development. If women cannot be actively part of networks that build social capital, economic development will be slower. According to the World Bank (2011), since women are usually care givers, they play an important role in the early development of social capital in a society. However, no country has ended gender discrimination yet and according to Picciotto, (1998; cited in The World Bank 2011), in a system where women are confined to their homes, not much social capital building can be expected. Levitt (2010) states that although the face of leadership has changed, the extent of any increase in women's leadership positions is uncertain, as traditional leadership models and expectations still create challenges for women.

Surprisingly, lack of social capital may even create health risks. For example, according to Sackey and Aminu (2011), social and cultural barriers like gender discrimination promote stagnation of women's upward mobility in business leadership positions and can create mental health issues for them. Furthermore, Edwards and Cheers (2007) state that mortality risk increases among women who experience the greatest degrees of social isolation (e.g. those with the fewest ties). Overall, those who lack social ties were about two to three times as likely to die within nine years as people who have many sorts of contacts (Edwards \& Cheers).

Furthermore, according to Guillen, Coromina, and Saries (2011), social capital is an important element for empowerment of men as well as women that reduces poverty. Social capital is created when individuals participate in civil society, but men and women do not have equal access to high-level positions as a result of women's lack of social capital. For women who aspire to become top leaders in business, the routes are full of expected and unexpected twists and turns (Eagly \& Carli, 2009). According to Picciotto (1998, quoted in World Bank 2011), gender discrimination erodes trust, hinders family relations, restricts social networks, and depletes social capital.

Glass ceiling: Douglas and Taylor (2012) state that the glass ceiling phenomenon impedes the advancement of intelligent women into senior executive positions in public corporations, and a "second glass ceiling" affects women who decide to establish their own businesses. This second glass ceiling is the gender bias that hinders women from having access to financial capital that is needed for either starting a new business or for expanding an existing one.

Women have fewer opportunities to advance to the executive level because of the glass ceiling, a metaphor describing obstacles in organizational hierarchies that impede women from rising to a higher level of leadership (Hymowitz \& Schellhardt, 1986). Also according to Osnes (2012), this lack of confidence and an unwillingness to exert vocal 
strength limits a woman's potential in the business world. Therefore, women who have reached the CEO level must share their stories and mentor other women (McDonagh \& Paris, 2012). Mattis (2004) observes that women do not have access to role models to the extent that males do. Also, Nixdorff and Rosen (2010) state that both female entrepreneurs and decision makers in business organizations tend to have similar leadership styles and do not have access to the same networks of role models as their male counterparts. However, women can learn leadership skills and are inclined to be effective because they are better listeners and tend to be empathetic (Applebaum, Audet, \& Miller 2003). In business organizations women's leadership styles and approaches tend to be more collaborative, participative, and democratic than the leadership styles of most men (Haber, 2011).

Another factor that reduces females' self-confidence is the male assumption that they are weaker than men and less able to lead (Andibo, 2012). In addition, women face other challenges, such as motherhood, career ambitions, and personal growth (Levitt, 2010).

In spite of all the challenges and barriers in the business world, women continue to seek leadership roles and want to secure leadership positions, especially in Western countries (Levitt, 2010). Education seems to be the main reason that women are deemed qualified to fill leadership positions. According to Levitt (2010), a report made by the United States Bureau of Labor Statistics in 2001 shows that women have earned $51 \%$ of all bachelor's degrees, $45 \%$ of all advanced degrees, $42 \%$ of all doctoral degrees, and $43 \%$ of all professional degrees, but the percentage of women in leadership positions is low. According to Galagan (2013), the situation has not changed dramatically since 1998. Galagan (2013) states that "Women make up 49 percent of the U.S. workforce, but they account for only 4 percent of corporate CEOs" (para. 1). Having higher education does not mean that women are easily hired into business leadership positions. For example, according to Levitt (2010), although the concept of leadership has changed within the counselling professions, traditional leadership is still the norm in the business world, and women's business leadership capabilities are often questioned.

The general challenges that women face worldwide also exist in Iran, but appear to be more serious. According to Safavi (2013), women who dare to challenge the validity or fairness of Iranian organizational norms often encounter frustration and disappointment. Muslim males often justify their oppression against women as honoring religious rules (McIntosh \& Islam 2010). According to Wiggins and Al-Obaidi (2013), based on stereotypes and prejudices, the rights of women in Middle Eastern countries are ignored and it is as if most of the extreme conventional authorities believe that the law of God can be implemented through the oppression of women. Many researchers state that higher education in Iran does not necessarily help women to work without problems and to gain leadership positions. For example, Mehdizadeh (2011states that in 2006 approximately $12.5 \%$ of the workforce in Iran was female, and her survey of 800 highly educated mothers shows the need for improvement of work-family balance for mothers to enable them to continue to participate in the labor force.

Education has made great changes in Iranian women's lifestyles (Iravani, 2012). According to Iravani (2012), "It is because of education, research and application that society has progressed the way it has, and it is the lack of education that perhaps can be blamed for many dark spots of human history, particularly for women" (para. 1). 


\section{Familial and Social Barriers}

According to Yazbeck and Espostio (1998), although Muslim governments borrowed political, economic, and legal models from Western institutions, family law in Muslim societies was not replaced by Western civil codes. In other words, although societies in the Muslim world may appear to be very modern, women still do not have the same rights and privileges as men.

Others note that Iranian women who cannot participate in physical exercise see marriage as the biggest limiting barrier to that pursuit (Dashti, Joseph, Esfehani, Su, Abd. Lattif, \& Esfehani, 2014). In another research study, Halimi et al. (2011) state that the main reason for male resistance is to prevent the financial independence of women.

\section{Cultural Barriers}

Culture and religion: It appears that Iranian values and beliefs create a dynamic that supports discrimination against women. The same restrictions exist in countries with cultures similar to Iran's culture (McIntosh \& Islam 2010).

Iran is a patriarchal country where men exert control on women's lives and employment (Shahidian, 2002). Katz, Stem, and Fader (2005) state that throughout history, women generally encountered many barriers and instances of inequality. Walby (1991) states that patriarchy exists in both traditional and modern societies, and that public patriarchy in the industrial world can be observed in the labor market. Iran is a neopatriarchal society where education, economic development, and modern attitudes are in direct contradiction to traditional and religious norms (Moghadam 2004).

Although there is a worldwide belief that Islam is the origin of patriarchal behaviours and beliefs, Shavarini (2003) notes that Iranian religions, particularly Islam, do not advocate limiting the education of females. Shavarini has also stated that "There is evidence that women's lower status prevalent in many Muslim societies is not a function of Islam, but rather of local cultural and social milieus where Islam was adopted" (para.2). However, the subject of the treatment of women in Muslim societies is one that creates strong debate, not only in Iran, but also around the world (Nomani, 2007).

Voll (2013) stated that the transition from a traditional society to the modern world may explain the reason behind oppression against women. Most of the crises in Muslim societies can be explained as a transition from traditional values to modern norms (Voll, 2013), and this transformation is very challenging.

\section{Political Barriers}

Challenges of reformists: As previously discussed, the interpretation of religion, particularly Islam, has a great role in creating discrimination against women. According to Labidi (2000), when a minister of education in the Tunisian government undertook the task of removing religious writings which favored discrimination against women from the school curricula, he was declared one of the principal enemies of Islam by fundamentalist Islamist groups. Liberalism in general, and women's rights in particular, may be seen as a threat by conservative groups in Muslim societies who often have their own interpretations of Islam. Adamson (2007) describes that in an Indonesian workshop where the interpretation of Islam was discussed, one male stated that even if discriminatory attitudes towards women are a case of misinterpretation of Islam, such interpretations are good for Indonesian women. His statement was supported by the other males in the group (Adamson).

For example, according to Iravani (2012), only 5\% of Iranian women have a decision-making role despite the 1995 national report which stipulates that in Iran, 5.7 percent of university professors, 16.5 percent of associate professors, 21.9 percent of 
assistant professors, and 36.9 percent of university instructors were women. In contrast, in 1998, 97.9 percent of parliament members were men and less than 2.2 percent were women (Iravani). According to UN data (2014), not much has changed since 1998. Since the Islamic revolution in 1979 only one female minister (Minister of Health) has been nominated by the government (Guardian, 2009). As a result, modernists are convinced that education is the primary path to enable women to assume leadership positions (Mahdi, 2007). According to Kian-Thiebaut (2006), "Modernists whose projects were focused on law, science, and progress aimed to transform the home by educating women, bringing them into public life, and remaking them into companionate wives of men of the nation" (para.5). In spite of political barriers, Iranian women use information technology to bypass those barriers (Abbasgholizadeh, 2014). Also Shirazi (2012) states that Internet and information technology has been used by Iranian women as a means of voicing their concerns about discrimination. Iranian women have the highest rate of Internet usage (49\%) among Islamic countries (Shirazi, 2012).

\section{Organizational Barriers}

According to Kephart and Schumacher (2005), women have been fighting for years for equality in pay, roles, and respect. Even in organizations that promote women's rights, the majority of leadership positions are held by men (Dawley, Hoffman, \& Smith 2004). Hein \& Chavez (2016) state that old mindsets are barriers for effectiveness of organizations and mindsets about women particularly form one the barriers. According to McDonagh and Paris (2012), "Women are often seen as nurturers and rarely as leaders. The stereotype of a strong, commanding, and male leader still influences decisions about placement in leadership positions" (para, 2). In business organizations around the globe there is a scarcity of women in leadership positions (Kochanowski, 2010). According to Kochanowski (2010), in 2008, only 15.2 percent of leaders in Fortune 500 companies and 9.7 percent of the leaders in the top 300 European corporations were females.

Because it is difficult or sometimes impossible for women to become leaders in business organizations where they work, many women prefer to establish their own businesses. According to Mattis (2004), women prefer to have flexible timing, independence, and self-control. Therefore, the number of self-employed women is increasing worldwide. Hakala (2007) states that according to studies done in the Centre of Women's Business Research by the U.S. Chamber of Commerce, the main reasons for women to choose to start their own businesses are financial independence and a passion for their chosen work. Comparing female business leaders to their male counterparts shows that making money is more important for male business leaders, while family and personal issues are a major motivation for women to establish their own businesses (Orser \& Dyke, 2009).

Although the number of self-employed women or female entrepreneurs is increasing worldwide, women are still underrepresented as leaders of business organizations and even more underrepresented in the political realm (Hakala, 2007). Iravani (2012) states that women do not have political leadership roles, but are tasked with carrying out decisions made by men. As a result, women have become disinterested in politics, and have shown signs of depression and pessimism in that domain (Iravani). For example, in Iran's 1998 parliament election, 97.86 percent of those elected were men and 2.2 percent were women (Iravani). In 2012, the number of female members in parliament was $8 \%$, a number that has not increased significantly in 15 years (Iravani). Therefore, 
there is evidence that education alone is not enough to empower Iranian women, as long as traditional attitudes remain unchanged.

\section{Organizational Culture}

According to Davis, Veguist, and Merrell (2007), surveys indicate that successful female business leaders develop a culture of trust and commitment in their firms and this culture is a main contributor to their successful financial and organizational performance. However, male-dominant organizational culture ignores women's competencies and abilities in leadership (Nixdorff \& Rosen, 2010).

However, female business leadership has been an interesting topic for research among scholars. A large number of researchers have corrected the historical inattention paid to female business leaders and their initiatives (Hughes, Jennings, Brush, Carter, \& Walter, 2012).

Ahl (2006) states that in spite of the growing number of studies about women's business leadership, there is a tendency to re-create the idea that women are secondary to men and that woman's businesses are less significant than their male counterparts' enterprises. In addition, the achievements of women are portrayed in the media as less important than men's accomplishments.

Jandeska and Kraimer (2005) state that the barriers hindering women from advancing in their careers at the same rate as men is called the opportunity gap. Inhospitable organizational cultures contribute to this gap (Ahl, 2006). Organizational culture is a combination of values and beliefs that shape behaviors and attitudes against women and may support opportunity gaps (Jandeska \& Kraimer, 2005). One of the findings in this literature review is the idea that organizational culture is one of the barriers hindering women and can undermine women's abilities.

\section{Data Collection and Analysis}

Data gathered from interview questions, survey questions, and individual feedback were analyzed. Survey questions based on the additional three questions enhanced the detail of personal status of the participants that is shown in Table 1. A majority of participants were between 40-59 years old and all of them were married. All participants had started to work immediately after graduation when they were between 20-29 years old. A majority of participants had children.

Table 1: Social Status of Participants

\begin{tabular}{|l|l|l|}
\hline \multirow{2}{*}{ Age of participants } & $29-39$ years old & $22.5 \%$ \\
\cline { 2 - 3 } & $40-59$ years old & $87.5 \%$ \\
\hline Age at start to work & $20-29$ years old & $100 \%$ \\
\hline \multirow{3}{*}{ Educational degree } & Bachelor degree & $12.5 \%$ \\
\cline { 2 - 3 } & Master degree & $62.5 \%$ \\
\cline { 2 - 3 } & PhD degree & $25 \%$ \\
\hline Marital status & Married & $100 \%$ \\
\hline \multirow{2}{*}{ Motherhood } & Have children & $87.5 \%$ \\
\cline { 2 - 3 } & Without children & $22.5 \%$ \\
\hline
\end{tabular}

The interpretation of the answers to survey questions is that those participants who have had good support from parents as well as husbands agree that there is familial support, while $37.5 \%$ of participants have had good support from parents but not from their husband and disagree with familial support because of conflicts that they have had with their husbands. Five of the eight participants see family as part of society, and although they 
have gained family support, they have faced challenges in the labor market; one participant has faced fewer challenges than the others, and two have experienced barriers that men put in the way of women in their progress.

In spite of investments in women's education the majority of participants do not see the political system supporting females. The reason can be contradictions between investment and support for education of women, and the barriers that they face later when they want to take part in social activities. The low number of female members of parliament and ministers in Iranian government also can be a basis of this kind of perception. Half of the participants see support in local culture and the other half doubt that support for females exists in local culture. This perception can be interpreted to mean that some women receive strong support from parents and sometimes from husbands, and therefore they do not see a lack of cultural support, but when they come to the labor market and meet men who are strangers to them they feel a lack of support and believe that patriarchal values are in the way of their progress.

Other survey questions were directly connected to research questions. All participants answered all the survey questions. Survey responses included participants' perception about family support, social and cultural support, and political support. The results below were extracted from survey questions.

The majority of participants see familial support for females' empowerment, although before marriage support is more evident, but after marriage it depends on the personal attitudes of the husband. The majority of participants see family or relatives as part of society and therefore their feedback is that society somehow supports females' empowerment. A majority of participants see the political system as the main barrier for females to obtain higher leadership positions.

Table 2. Individual Feedback Results

\begin{tabular}{|l|r|r|}
\hline Question & Responses & Percent who agree \\
\hline Family support & Parents support & $65 \%$ \\
& Husbands support & $35 \%$ \\
\hline Iranian society support & Yes & $25 \%$ \\
& Somewhat & $50 \%$ \\
& Not at all & $25 \%$ \\
\hline Political system support & Yes & $12.5 \%$ \\
& Somewhat & $25 \%$ \\
& Not at all & $62.5 \%$ \\
\hline Local culture support & Yes & $25 \%$ \\
& Somewhat & $50 \%$ \\
& Not at all & $25 \%$ \\
\hline
\end{tabular}

\section{Interview Findings}

For data analysis without prejudice, the qualitative program NVivo 11 was used to generalize the data and free nodes were created and placed in related categories. After original nodes were created they were identified and added to groups. After sorting the data, categories were created to reflect the perceptions of participants. The answers of each participant to the eight interview questions, as well as answers to survey questions and individual feedback, were used to authenticate themes. Saturation occurred when answers did not produce new themes and continued analysis produced previously identified themes. 
To analyse gathered data the method of Leedy and Ormrod (2010) was used. In this methodology, after each interview the data was entered into the software and after several examinations, semantic units were detected one by one and initial coding was done. After the initial interviews, classification was based on comparisons of differences and similarities between the codes, and the classes became more complete; as necessary, classes were merged into each other.

With the help of NVivo 11 software 16 themes were extracted from interview results. Among them, four themes that were directly related to research questions were selected. According to the technique suggested by Evand, Gruba, and Zobel (2014), data findings were categorized according to the research questions.

Results of interviews are shown in Table 3. Results align with the literature review and research questions. The perception of participants were that beside social and cultural stereotypes; the political system has contradictions for the empowerment of females. On one hand investments for females' education is high, but on the other hand there are limitations in law and regulations that hinder women from achieving higher positions.

Table 3. Result of Interviews

\begin{tabular}{|l|r|r|}
\hline Question & Responses & Percent who agree \\
\hline Family support & Parents & $75 \%$ \\
& Husband & $25 \%$ \\
\hline Social and cultural support & Yes & $12.5 \%$ \\
& Somehow & $37.5 \%$ \\
& No & $50 \%$ \\
\hline Political support & No & $100 \%$ \\
\hline Religious support & No & $100 \%$ \\
\hline
\end{tabular}

\section{Compilation of Results}

In this case study sources for triangulated data were a survey, individual feedback, and interviews. The same questions were presented to all participants until data saturation occurred. Responses to the survey, individual feedback, and eight interview questions in this qualitative single case study helped to create and develop themes. The responses of participants confirmed that women who have been trying to gain business leadership positions have faced and perceived pressure or inequality. The findings are organized in four thematic groups. Participants stated that they did not see a chance for their growth in large organizations; although they achieved high positions, keeping the position was challenging because their male colleagues were not cooperating or sometimes poisoning the atmosphere.

All participants believed that Iranian society is patriarchal and that there are stereotype thoughts among some people (even females) that the main job of a woman is to take care of her children and to be a housewife. Although in big cities this kind of stereotype thinking is disappearing, still there are jokes or comments among people about the competencies of women in important decision making. Participants saw a bright future for females and believed that, in spite of some discrimination, females pave the way for their development and society is adapting to women's progress.

All participants believed that the political system invests well in the education of females, but nevertheless they face barriers when they enter the job market. For example, for traveling abroad women need permission of their husbands. This gives full control to 
husbands to dictate their will. The political system wants to show off female leaders in some organizations just for international ratings and propaganda; however, in the last 40 years only one female minister has been in the cabinet and she was forced to resign. The number of female members of parliament is much smaller than the number of male members.

The concept of family has two meanings for participants: one is before marriage, and the second is after marriage. Family support from parents is not a challenge, but after marriage cooperation of the husband can be a challenge. Society and culture seemed to be two concepts in the minds of participants. Family and culture are seen as part of society with a positive experience for participants, but most of the participants have faced challenges and discrimination in the labor market. All participants criticized the political system as the main barrier for women's empowerment. Even efforts by politicians to encourage participation of females in positions of power were interpreted as show by all participants. Although the role of religion was not designed in interview questions and the researcher did not ask anything about religion, nevertheless comments of a majority of participants added new data on that topic that is mentioned in research findings.

Data findings show there is a contradiction between huge investments for females' higher education and the regulations, lobbying, and laws that are barriers for empowerment of females. Changing those regulations and facilitating women's participation in high-level decision making may lead to better economic results in the country.

All participants were married and a majority of them had children. Additional research on single females who try to gain business leadership positions may lead to different findings. The researcher did not have access to public sector records. Therefore, future research on female leaders in other parts of Iran as well as research on unmarried leaders and women's challenges in public sector is recommended.

\section{Significance of Study}

There are many similarities for businesswomen in all Middle Eastern and North African (MENA) countries (Wolf, 2015). About $50 \%$ of the population in countries like Iran are females and such countries need work force participation by both men and women to build the country (Ebrahimian, 2003). The results of this study can add to accurate and first-hand information about the challenges women face in this part of the world. A critique of social and cultural values in the Middle East can yield a better balance between genders. (Ghanim, 2009). Knottes, Jones, and LaPereze (2004) stated that the number of studies comparing women to men in Middle Eastern countries is small, and therefore this study may be useful for more clarification about the contribution of women business leaders in a male-dominated country. The significance of the study to leadership is that it may provide insights into a problem that has not yet been fully examined in the Middle East and North Africa (Owen, 2000).

\section{Research Limitations and Future Directions}

The primary limitation of this study is that its focus is on a group of Iranian females who have had challenges in gaining business leadership positions. Since the proposed participants live in Tehran, their experiences may not represent those of Iranian women in other locations. Therefore, the study results are limited to this particular group and place and may not be generalizable to other groups.

In addition, the researcher does not have free access to Iranian governmental statistics, which might be useful in providing information regarding female-owned 
business ventures. Furthermore, this study was limited to perceptions that participants have about the obstacles which prohibit them from advancing in business leadership. Since the researcher may have biases related to the study's focus, he refrained from commenting during the data gathering processes. It was explained to participants that the researcher would not make any comment to avoid biases. In spite of these limitations, the interview questions have been designed to make research results robust (Leedy \& Ormrod, 2010).

\section{Conclusion}

The purpose of this qualitative single case study was to explore barriers that Iranian female businesswomen perceive in gaining business leadership positions. An interpretation of the findings is that parents encourage their female children to achieve higher education. Also, some husbands support their wives and some husbands are the main barrier in the way of their spouses. Technology and the economy play an important role in changing stereotypes about women. Political systems want women in leadership positions as a tool to increase international ratings, but in practice the engagement of capable females is at a low level. Also, in traditions based in religion, females are weaker than men. In spite of barriers and limitations the percentage of female university students is $60 \%$, and although only $10 \%$ of women are in leading positions, the activities of women in NGOs advertise their willingness and capabilities to be leaders. Women who do not give up pave the way for women to succeed despite gender discrimination.

\section{Acknowledgments}

This paper has been prepared from the thesis submitted for the Degree of Doctor of Management at University of Phoenix, USA. I would like to express my appreciation and thanks to those who helped me to conduct the research and complete this study. Special thanks to my chair who guided me through this study and was my main source of encouragement. I appreciate the contribution of other committee members who made this report more complete. Furthermore, I acknowledge with much appreciation the important role of the Association of Iranian Female Entrepreneurs that made this research possible. Interviewees were members of the association with good experience in business management and leadership. Also, I want to thank my family who supported me in this journey.

\section{References}

Abbasgholizadeh, M. (2014). To do something we are unable to do in Iran: Cyberspace the public share, and the Iranian women movement. The University of Chicago Press Journals, 39(4).

Abdo, G. (2006). Iran awakening: A memoir of revolution and hope. The Middle East Journal, $60(4)$.

Adamson, C. (2007). Gendered anxieties: Islam, women's rights, and moral hierarchy in Java 1, Anthropological Quarterly, 80(1).

Ahl, H. (2002). The making of the female entrepreneur. Jonkoping University, School of Education and Communication. Retrieved from: https://www.researchgate.net/publication/265533157_The_Making_of_the_Female_Entr epreneur_A_Discourse_Analysis_of_Research_Texts_on_Women's_Entreprenership.

Ahl, H. (2006). Why research on women entrepreneurs needs new directions. Entrepreneurship Theory and Practice, 30(5). Retrieved from http://onlinelibrary.wiley.com/doi/10.1111/j.1540 6520.2006.00138.x/abstract 
Andibo, A. (2012). Obstacles women face in participating effectively in trade union membership and leadership. Journal of Emerging Trends in Educational Research and Policy Studies, $3(3)$.

Applebaum, S. H., Audet, L, \& Miller, J. C. (2003). Gender and leadership? Leadership and gender? A journey through the landscape of theories. Leadership \& Organization Development Journal, 24(112), 43-52.

Arasti, Z. (2012). A Qualitative study on environmental factors affecting Iranian women entrepreneurs, growth orientation. Journal of Management and Strategy, 3(2).

Balaghi, S. (2014). A brief history of 20th-century Iran. Retrieved from http://www.nyu.edu/pages/greyart/exhibits/iran/briefhistory/

Bianchi, S. (2005). Competing devotions: career and family among women executives. Journal of Marriage and Family, 67(3).

Brown, E. (1966). The Persian revolution of 1905-1909. New York: Barnes \& Noble.

Cooke, M. (2000). Women claim Islam: Creating Islamic feminism through literature. Rutledge, NY.

Dashti, S. H., Joseph, L., Esfehani, A. J., Su, T. T., Latiff, L. A., \& Reza Jafarzadeh Esfehani. (2014). Perceived barriers to physical activity among Iranian women. Department of Community Health, Faculty of Medicine and Health Sciences, 1 University Putra Malaysia. Retrieved from: http://citeseerx.ist.psu.edu/viewdoc/download?doi=10.1.1.721.2323\&rep=rep1\&type=pdf

Davis, J., Vequist, D. G., \& Merrell, R., (2007). An exploration of the trust commitment cultural model and its role in the success of women entrepreneurs, Advancing Women in Leadership Online Journal, Vol. 24, Spring 2007.

Dawley, D., Hoffman, J. J., \& Smith, A. R. (2004). Leader succession: Does gender matter? Leadership \& Organization Development Journal, 25 (7/8), p. 678.

Douglas, B., \& Taylor, P. (2012). The second glass ceiling impedes women entrepreneurs. Journal of Applied Management and Entrepreneurship, 17(1).

Eagly, A., \& Carli, L. (2009). Women and labyrinth of leadership, Harvard Business Review. https://hbr.org/2007/09/women-and-the-labyrinth-of-leadership

Ebrahimian, L. (2003). Socio-economic development in Iran through information and communications technology. The Middle East Journal, 7(1).

Edwards, J., \& Cheers, B. (2007). Is social capital good for everyone? The case of same-sex attracted women in rural Australian communities. Health Sociology Review, 16(3-4).

Evand. D, Gruba, P., \& Zobel, J. (2014). How to write a better thesis (3 ed.). Switzerland: Springer International Publishing.

Galagan, P. (2013). MIA: Women in the executive suite: Women with leadership capabilities are abundant. Why aren't they getting the top jobs? Leadership report, T\&D, 67(7).

Ghanim, D. (2009). Gender and violence in the Middle East. Praeger.

Given, L. M., \& Saumure, K. (2008). The Sage encyclopedia of qualitative research method.

Guillen, L., Coromina, L., \& Saris, W. E. (2011). Measurement of social participation and its place in social capital theory. Social Indicators Research, 100(2).

Haber, P. (2011). Iron sharpens iron: Exploring the experiences of female college student leaders. Advancing Women in Leadership, 31.

Hakala, R. (2007). Women entrepreneurs: Challenges and successes in non traditional industries. Phoenix, AZ: University of Phoenix.

Halimi, A. B., Chavosh, A., Sharifi, A., Namdar, J., \& Behjati, S. (2011). Entrepreneur women in Iran: A review of challenges and approaches to remove the barriers of women entrepreneurship in Iran. Shanghai, China: International conference on economics business and marketing management (EBMM 2011), 114-117. Available at SSRN: https://ssrn.com/abstract $=2009246$

Hein, S., \& Chavez, G. (2016). Shifting from transactional leadership (T2) to transformational leadership (T3) behavior with full range leadership development program (FR-LDP) OD intervention, ABAC ODI Journal: Vision. Action. Outcome. 3, 1 (January 2016), 70-101 
Hughes, K. D., Jennings, J. E., Brush, C., Carter, S., \& Walter, F. (2012). Extending women's entrepreneurship research in new directions. Entrepreneurship: Theory and Practice, $36(3)$.

Hymowitz, C., \& Schellhardt, T.D. (1986, March 24).The glass-ceiling: Why women can't seem to break the invisible barrier that blocks them from top jobs. The Wall Street Journal.

Iravani, M. (2012). Role of education in employment opportunities for women in Iran as an important factor for the sustainability of the society, European Journal of Sustainable Development, 1(1).

Isfandyari-Moghadam, A., Hasanzadeh, M., \& Ghayoori, Z. (2012). A study of factors affecting research productivity of Iranian women in ISI. Sientometrics, 91,159. doi:10. 1007/s11192-011-0585-5

Jandeska, K. E., \& Kraimer, M. L. (2005). Women's perceptions of organizational culture, work attitudes, and role-modeling behaviors. Journal of Managerial Issues, 17(4).

Javadian, G., \& Singh, R. (2012). Examining successful Iranian women entrepreneurs: An exploratory study. Gender in Management: An International Journal, 27(3), 148-164

Kamyab, S. (2004). Education in Iran: An Overview. College and University, 79(4).

Kashani-Sabet, F. (2011). Conceiving citizens: Women and the politics of motherhood in Iran. Oxford University Press, 2011

Katz, M.B., Stem, M.J., \&Fader, J.J. (2005, Fall). Women and the paradox of economic inequality in the twentieth-century. Journal of Social History, 39 (1), 65-90.

Kephart, P., \& Schumacher, L. (2005). Has the 'glass ceiling' cracked? An exploration of women entrepreneurship. Journal of Leadership \& Organizational Studies, 12(1).

Kian-Thiébaut, A. (2006). Women with mustaches and men without beards: Gender and sexual anxieties of Iranian modernity. The Middle East Journal, 60(1).

Knotts, T. L., Jones, S. C., \& LaPreze, M. W. (2004). Effect of owners' gender on venture quality evaluation. Women in Management Review, 19, 74-87.

Kochanowski, S. (2010). Women in leadership: persistent problems or progress? Forum on public policy: A Journal of the Oxford Round Table, Summer 2010.

Labidi, K. (2000). Tunisia: (Islam and Freedom: The historic misunderstanding). The Middle East Journal, 54(3).

Leedy, P. D., \& Ormrod, J. E. (2010). Practical Research (9 ed.). Upper Saddle River, NJ: Merrill. Levitt, D. (2010). Women and leadership: A developmental paradox? Adultspan Journal, 9(2).

Mahdavi, S. (2003). Women in Iran: Gender politics in the Islamic republic. The Middle East Journal, 57(4).

Mahdi, A. (2004). The Iranian women's movement: A century long struggle. The Muslim World, 94. Retrieved from: https://onlinelibrary.wiley.com/doi/abs/10.1111/j.14781913.2004.00067.x

Mahdi, A. (2007). IRAN: Tehran Blues: Youth culture in Iran/warring souls; youth, media, and martyrdom in post revolution Iran. The Middle East Journal, 61(1).

Mattis, M.C. (2004). Women entrepreneurs: Out from under the glass ceiling. Women in Management Review, 19(3), 154.

McDonagh, K., \& Paris, N. (2012). The Leadership labyrinth: Career advancement for women, Frontiers of Health Services Management, 28(4).

McIntosh, J, \& Islam, S. (2010). Beyond the veil: The influence of Islam on female entrepreneurs in conservative Muslim context. International Management Review, 6(1).

Mehdizadeh, N. (2011). Gender and reconciliation of work and family in Iran. International Labour Review, 150(3/4).

Mili, A. (2013). Gender standards vs. democratic standards: Revisiting the paradox. Journal of International Women's Studies, 14(2), 3-11.

Moghadam, V. (2004). Patriarchy in transition: Women and changing family in the Middle East. Journal of Comparative Family Studies, 35(2).

Mohammadi, M. (2007). Iranian women and the civil rights movement in Iran: Feminism interacted. Journal of International Women's Studies, 9(1). 
Moinifar, H. S. (2012). Higher education of women in Iran: Progress or problem? International Journal of Women's Research, 1(1).

Morley, L. (2014). Lost leaders: women in global academy, Higher Education Research \& Development, 33, 114-128.

Neuman, W. (2009). Social research methods: Qualitative and quantitative approaches. (7ed.). Upper Saddle River: NJ: Prentice Hall.

Nickerson, M. (2012). Mothers of conservatism: Women and the postwar rights. Princeton, NJ: Princeton University Press.

Nixdorff, J., \& Rosen, T. (2010). The glass ceiling women face: An examination and proposals for development of future women entrepreneurs. New England Journal of Entrepreneurship, $13(2)$.

Nomani, A. (2007). A faith of their own: Muslim women seek the renewal of Islam. Sojourners Magazine, 36(3).

Nuket, K. (2002). The emergence of a global gender equality regime. GEMC Journal, 57(3).

Orser, B., \& Dyke, L. (2009). The influence of gender and occupational-role on entrepreneurs' and corporate managers' success criteria. Journal of Small Business and Entrepreneurship, 22(3).

Osnes, B. (2012). Voice strengthening and interactive theatre for women's productive incomegenerating activities in sustainable development. Journal of Sustainable Development, 5(6).

Owen, R. (2000). State, power, and politics in the making of the modern Middle East (2 ed.). Routledge., Taylor and Francis Group, (2008).

Richardson, E. (2013). Gender Jihad: The slow and steady gains of women in the Middle East. Journal of International Affairs, 67(1).

Sackey, J., \& Aminu, S. M. (2011). Social support as mental health improver for managerial women in the organizational work environment. Business Intelligence Journal, 4(2), 356.

Safavi, F. (2013). Emerging profiles of female marketing managers in the Islamic Republic of Iran: Winning and losing competitive laps in relay race against male counterparts. International Journal of Marketing Studies, 5(3).

Sarafraz, L. (2017). Women's entrepreneurship in Iran: A comparative perspective. Springer Nature, Switzerland (2017).

Sarafraz, L., \& Faghih, N. (2011). Women's entrepreneurship in Iran: A GEM based-data evidence. Journal of Global Entrepreneurship Research, 1(1).

Semali, L., \& Shakespeare, E. (2014). Rethinking mindscapes and symbols of patriarchy in the workforce to explain gendered privileges and rewards. International Education Studies, $7(2)$.

Shahidian, H. (2002). Women in Iran. Praeger (August 30, 2002).

Shavarini, M. (2003). Misconceptions about Islam and women's education: Lessons from the Islamic Republic of Iran. International Education, 33(1).

Shirazi, F. (2012). The Islamic veil in civil societies. International Academic Journal. Retrieved from:https://www.google.com/search?q=Shirazi\%2C+F.+(2012).+The+Islamic+veil+in+ci vil+societies.+International+Academic + Journal.\&rlz=1C1GGRV_enAE753AE753\&oq $=\mathrm{S}$ hirazi\%2C+F.+(2012). + The+Islamic + veil + in + civil + societies. + International+Academic + Jo urnal.\&aqs $=$ chrome..69i57.554j0j4\&sourceid $=$ chrome $\& \mathrm{ie}=\mathrm{UTF}-8$

Shirazi, F. (2012). Information and communication technology and women empowerment in Iran. Telematics and Informatics, 29(1).

Sorokina, M. (2014). Women not yet "on board." Bureau of Labor Statistics.Retrieved from https://www.bls.gov/opub/mlr/2014/book-review/women-not-yet-on-board.htm

The Guardian. Retrieved from http://www.theguardian.com/world/2009/sep/03/iran-woman cabinet-minister

The World Bank. Retrieved from http://data.worldbank.org/indicator/SP.POP.TOTL.FE.ZS

The World Bank. Retrieved from: http://www.worldbank.org/en/search?q=growth+middle+east+2014\&currentTab=1 
Vavrus, F. (2003). Women and development: Rethinking policy and reconceptualising practice. Women's Studies Quarterly, 31 No. (3)

Vermaseren, M. J. (1963). Mithras: The secret God. London: Chatto and Windus, p. 29.

Voll, J. (2013). Philosophy, religion, and science: Islam and the Arab Awakening The Middle East Journal, 67(2).

Walby, S. (1991). Theorizing patriarchy, Basil Blackwell, Cambridge, MA.

Wiggins, S., \& Al-Obaidi, J. (2013). Women and gender in the Middle East: Recognition, reflection, and realignment: A Bridgwater State University Conference. Journal of International Women's Studies, 14(2).

William K. Sham, "Women's higher education and the brain drain in Iran," Armstrong Undergraduate Journal of History 2, no. 1 (Jan. 2012).

Wolf, A. (2015). Business women in the Middle East and North Africa, barriers and opportunities. A senior thesis submitted in partial fulfillment of the requirements for graduation from the honors program of Liberty University. Retrieved from https://digitalcommons.liberty.edu/cgi/viewcontent.cgi?article $=1513 \&$ context=honors

Woolcock, M., \& Narayan, D. (2000). Social capital: Implications for development theory, research, and policy. World Bank Research Observer, 15(2), 225-250.

Yazbeck, Y., Espostio, J. (1998). Islam, gender, and social change, Oxford University Press. 